\section{Forfeiting Citizenship, Forfeiting Identity? Multiethnic and Multiracial Japanese Youth in Australia and the Japanese Nationality Law}

\section{AOIFE WILKINSON}

The University of Queensland

(D) https://orcid.org/0000-0003-0994-4705

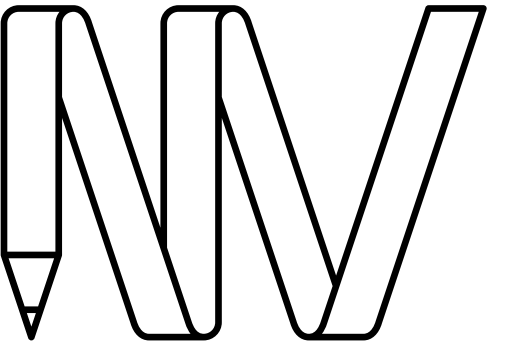

NEW

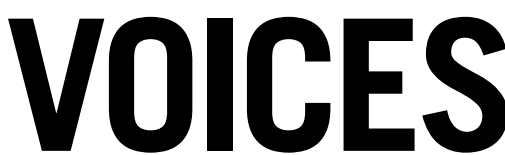

IN JAPANESE STUDIES

\title{
ABSTRACT
}

The rising fame of multiethnic and multiracial or 'mixed' celebrities in Japan, such as tennis player Naomi Osaka, has brought into focus the roles of Japan's Nationality Law and understandings of nationality and citizenship in shaping identity. According to Article 14 of Japan's Nationality Law, persons holding multiple nationalities must choose to forfeit all but one before the age of 22. In this article I aim to address how multiethnic and multiracial youths of Japanese descent in Australia are approaching the ambiguities surrounding their citizenship and nationality rights. To do so I will closely examine to what extent the Nationality Law affects their future decisions and identities by drawing upon evidence from in-depth interviews I conducted with mixed Japanese youth who are the child of one Japanese parent and one non-Japanese parent and live in Australia. Using Pierre Bourdieu's theory of cultural capital, I argue that mixed Japanese youth in Australia perceive citizenship less as an agent of identity and more as an index of socioeconomic opportunity. My findings demonstrate that these individuals actively strive to maintain their dual citizenship and strategically align their cultural capital to realise meaningful cross-cultural careers that communicate between Australia, Japan, and their own mixed identities.

\section{KEYWORDS}

Australia; careers; citizenship; contemporary; cultural capital; hafu; Japanese Australian; law; mobility; multiethnic identity; nationality law; Nikkei; social and cultural identity; youth

\section{JAPANFOUNDATION 8 BRINGING JAPAN TO YOU \\ To link to this article: https://doi.org/10.21159/nvjs.12.02 \\ ISSN 2205-3166 \\ New Voices in Japanese Studies is an interdisciplinary, peer-reviewed journal showcasing the work of emerging scholars with ties to Australia or New Zealand and research interests in Japan.}

All articles can be downloaded free at newvoices.org.au

(c) The Japan Foundation, Sydney and Aoife Wilkinson, 2020.

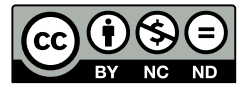

This work is licensed under a Creative Commons Attribution-NonCommercialNoDerivatives 4.0 International License. 


\section{INTRODUCTION}

On October 10,2019, just days before she was to turn 22, tennis player and American-Japanese dual national Naomi Osaka announced that she had chosen to forfeit her American nationality in accordance with the Japanese Nationality Law (国籍法; hereafter, 'Nationality Law') (NHK News 2019). In the year leading up to her decision, pundits and sports fans in both the US and Japan had questioned Osaka's preferred nationality, and speculated about which nation she would choose to represent for the remainder of her career. American media outlets like The New York Times framed Osaka as an ethnically mixed celebrity who was redefining what it means to be Japanese (Rich 2018). Meanwhile, in Japan, many questioned why mainstream Japanese news sources were conveniently positioning Osaka as 'quiet' and 'shy', two stereotyped characteristics of an ideal Japanese woman (Burgess 2018; Yamada 2018; Iwase 2018). The global media response to Osaka's decision in the face of the Nationality Law prompted the public to debate the extent to which ethnic identity determines a person's nationality, and furthermore, who or what determines a person's ethnic identity in the first place.

As Chris Burgess (2018) writes, Osaka's nationality and identity has brought to our attention the issue of Japan's myth of ethnic homogeneity (単一民族) and the nihonjinron (日本人論) discourses which work to render Japanese identity as exclusive and essentialist. ${ }^{1}$ In his earlier work, Burgess (2004) explains how multiethnic Japanese like Osaka, known as häfu (ハーフ) in Japan, are constantly pushing and pulling against the established ethnonational Japanese identity found within active discourses like nihonjinron to establish their own membership within Japanese society. ${ }^{2}$ An expansive array of literature has investigated the identities of mixed Japanese both within (e.g., Törngren 2018; Takeshita 2019) and outside of Japan (e.g., Suzuki 2011; Yamashiro 2017; Shao-Kobayashi 2019), as well as the area of mixed Japanese and Japan's Nationality Law (Hara 2018). ${ }^{3}$ My article contributes to this body of work by examining a so-far overlooked demographic within Japanese identity studies: mixed Japanese youth in Australia.

In this article, I will first define citizenship and nationality and explain the Nationality Law, its ambiguity, and the history of activism that surrounds it. I will then discuss how mixed Japanese youth in Australia are navigating the Nationality Law and examine the extent to which the law affects their decisions and sense of identity. To do so, I will draw upon interview data I collected in 2019 from 14 participants between the ages of 18 and 24, where

1 Japan's myth of ethnic homogeneity has been discussed widely but most notably by sociologist Eiji Oguma (1995), who argues that post-war Japanese society was collectively consumed by the myth that Japan has always been an ethnically homogenous nation, despite evidence of early international migration that demonstrates otherwise. Additionally, nihonjinron is a genre of academic and popular literature that remains active in public discourse, and has produced various essentialised analyses of Japanese identity with a focus on three themes: appearance (ethnicity or race), nationality and language/cultural proficiency (Sugimoto 1999).

$2 \mathrm{Ha} f u$, a derivative of the English world 'half', refers to Japanese persons of mixed race and/or ethnicity. The emergence of the term has been traced back to the early 1990s. Many have argued that häfu is a derogatory term that frames mixed Japanese persons as literally 'half' or 'less than' a Japanese person (Murphy-Shigematsu 2000; Yamashiro 2017).

3 I have borrowed the phrase "mixed persons" from the work of Sayaka Osanami Törngren (2018), who uses it as shorthand for "multi-ethnic and multiracial" to refer to "someone who has parents of differing racial and ethnic backgrounds" (749). 'Race' is a social construct that often implies biological differences, whereas 'ethnicity' as a construct evokes notions of culture, symbols, group identity or collective memory (Song 2003). As Song argues, it is difficult to refer to race without also speaking of ethnicity $(2003,11)$. Therefore, in the context of this article, 'mixed Japanese' refers to persons who are in part ethnically and/or racially Japanese. 
each interviewee was the child of a Japanese and a non-Japanese parent, and was living in Australia at the time. The majority of interviews were conducted in English, with some Japanese used by participants to refer to culturally specific phenomena.

My findings demonstrate that mixed Japanese youth in Australia perceive themselves as mostly unaffected by the Nationality Law due to its lack of enforcement in Japan and abroad by the Japanese Ministry of Justice (法務 省). In contrast with the strong relationship between identity and citizenship in the case of Naomi Osaka's citizenship decision, as highlighted by the media hysteria surrounding it, I argue that most mixed Japanese youth in Australia value citizenship predominantly as an index of socioeconomic opportunity and less as a marker of identity. I further argue that the value placed upon the economic authority of citizenship status by mixed Japanese youth in Australia is proven by the ways in which they strategically maintain their dual citizenship status as cultural capital to help build their employability, increase their mobility and achieve cross-cultural careers. Pierre Bourdieu's (1986) theory of cultural capital is an application of economic theory to sociology which holds that each individual embodies specific cultural knowledge and skills (i.e., cultural capital) that they can use to produce new relationships and products. I have applied Bourdieu's theory of cultural capital to my findings to help understand the culturally specific skills and knowledge that mixed Japanese youth in Australia leverage to produce desirable economic and personal outcomes.

\section{CITIZENSHIP AND NATIONALITY}

It is important to first note the significant difference between the use of the anglophone term 'citizenship' and its nearest Japanese equivalent, 'shiminken' (市民権). According to Tessa Morris-Suzuki, in English the word 'citizenship' conflates both (1) nationality, expressed by the term 'kokuseki' (国籍) in Japanese, and (2) political and social rights, which the Japanese term 'shiminken' represents $(2015,68)$. According to an Australian Department of Immigration and Citizenship report titled Citizenship and Immigration, an example of political and social rights in the Australian context may include the right to vote in elections, thereby denoting a formal establishment "of membership (in the) national community" (Smith et al. 2010, 3). This demonstrates that the act of voting (the 'shiminken' dimension of citizenship) is directly linked to national membership (i.e., nationality; the 'kokuseki' dimension of citizenship) in Australian official discourse.

On the other hand, in Japan, nationality (kokuseki) and citizenship (shiminken) are understood as two separate entities: as a blood right, and as legal rights and "capabilities", respectively (Morris-Suzuki 2015, 68). What Morris-Suzuki refers to when speaking of the "capabilities" of citizenship is

The ability to live securely in a particular place, to have access to various forms of social welfare and protection, to participate actively in various sorts of autonomous and social forums, and to participate in the political life of the state.

(Morris-Suzuki 2015, 69) 
Morris-Suzuki (2015) argues that there are various forms of "semi-citizenship" in Japan, and that each form dictates the varying level of capabilities of each resident (67). She goes on to expose the institutionalised marginalisation that dictates the varying forms of semi-citizenship that exist in Japan underneath the apex title of the "full citizen", a Japan-born, Japanese national (MorrisSuzuki 2015, 67). ${ }^{4}$ One example is the form of citizenship titled 'special permanent resident' (特別永住者) which is typically held by Zainichi Koreans (在日韓国人; 在日朝鮮人). 'Zainichi' (在日; lit., 'residing in Japan') is a Japanese term used to refer to pre- and post-war forced and unforced migrants in Japan, and their descendants (Chapman 2008). Zainichi Koreans, therefore, are migrants from the Korean peninsula and their descendants. ${ }^{5}$ According to Green (2013), Zainichi Koreans are afforded the title 'special' because they "do not have to apply directly for permanent residency in Japan"; however, they have fewer capabilities than a Japanese citizen because they are prohibited from voting in elections and holding positions in government (n.p.). ${ }^{6}$ Unlike permanent residency categories of the US or Australia, "special permanent residence status in Japan is no guarantee of eventual [full Japanese] citizenship", which can only be obtained via the long and difficult process of naturalisation (Ryang 2008, 12). Nationality (kokuseki) is therefore positioned in Japan as unalterable and the height of an official claim to membership in Japanese society. This is in part because Japanese nationality is legally ascribed on the basis of the nationality of the child's parents (jus sanguinis) and not by birth on Japanese soil (jus soli). ${ }^{7}$

In this article, when discussing the dual nationalities of the Australia-based participants in my study and their decisions to forfeit a nationality, I will use the term 'citizenship' (shiminken) rather than 'nationality' (kokuseki). This reflects the word choice of the participants, who solely used the word 'citizenship' during interviews. When discussing the Nationality Law in the context of mixed Japanese dual nationals in Japan, such as in the following paragraph, I will use the term 'nationality'.

\section{THE JAPANESE NATIONALITY LAW}

According to the Japanese Ministry of Justice website, Article 14 of the

\footnotetext{
4 See Morris-Suzuki (2015) for further explanation of the distinction between nationality and citizenship in the Japanese context.

5 According to Sonia Ryang (2008), "Koreans in Japan had no official nationality available [to] them" prior to 1965 (8). The semi-citizenship category of 'special permanent resident' was created in 1965 after the signing of the normalisation treaty between the Republic of Korea (ROK) and Japan. The category of 'special permanent resident' enabled Zainichi Koreans to access Japanese public health and education services and thereby improved "the legal status of the ROK-affiliated (South Korean) Zainichi population" who were eligible for the category (Chapman 2008, 70). However, this meant that to be eligible for the special residency status and gain access to public welfare, Zainichi Koreans had no choice but to claim South Korean (韓国) nationality, "even though for some this was in direct opposition to their ideological position" (Chapman 2008, 32). It was only after revisions in 1992 that all former colonial subjects from North and South Korea and Taiwan who had been living in Japan since 1945 were unified under the status of 'special permanent resident' (Söderberg 2011; Chapman 2019). Today, North Korea is not recognised as a sovereign state by Japan, and "a minority of Koreans in Japan continue to have chōsen [朝鮮; lit., the former undivided 'Korea', but a term now often associated with North Korea] listed as their nationality even though chōsen is not a formally recognised nationality in Japan" (Ryang 2008, 8).

6 Japan's Liberal Democratic Party has long argued that granting permanent foreign residents the right to vote is "unconstitutional" and would hinder "the already low naturalization rates among Korean residents" (Chung 2010, 115).

7 Claims to Japanese nationality outside of Japan are particularly complex due to the relationships between the Japanese judicial system, the Nationality Law and Japan’s koseki (戸籍; family registry) system (Hara 2018).
} 
Nationality Law maintains that a Japanese national who also holds a foreign nationality must choose to forfeit one of those nationalities before they reach the age of 22 (Ministry of Justice n.d.[a]). This law lies in accordance with the principle of jus sanguinis (nationality by right of blood), as opposed to jus soli (nationality by right of soil or location of birth) and operates closely in coordination with the Japanese National Family Registry or koseki (戸籍) system (Gottlieb 2012).

However, many studies have shown that the Nationality Law's stipulation of a single nationality for Japanese citizens differs greatly from the reality of the situation, because many mixed Japanese have been able to maintain dual nationality past the age of 22 (Takeda 2005; Murakami and Baird 2018; Takeda 2018). For example, of 1,449 Japanese dual citizens surveyed by The Japan Times, a leading English-language newspaper in Japan, 76.8\% of respondents stated that they had maintained both of their passports past the age of 22 (Murakami and Baird 2018). As Murakami and Baird highlight, this is due in part to two reasons: (1) "the [Nationality Law]...fails to specify any penalties against dual nationals who do not pick a nationality", and (2) the Japanese government has no specific means of measuring how many Japanese citizens hold multiple nationalities (2018, n.p.). In addition, I suggest that the process behind forfeiting nationality has also contributed to a lack of cooperation with the Nationality Law.

According to the Ministry of Justice website, if a dual national decides to forfeit their nationality whilst in Japan or overseas, the onus is on the dual national to approach their local embassy or government office to begin the application (Ministry of Justice n.d.[b]). A Ministry of Justice official disclosed to Murakami and Baird that the "right to warn such nationals under the 1985 revision of the Nationality Law has never been exercised...partly because the act of tracking down citizens with multiple nationalities and encouraging them to make a choice would be a bureaucratic nightmare" (2018, n.p.). However, the article cites several multinational persons recounting occasions where, on a routine visit to their local municipal office in Japan, they were made to forfeit one or more of their nationalities on the spot (Murakami and Baird 2018). These first-hand accounts signify the unpredictable enforcement of the Nationality Law and echo anxieties articulated by numerous mixed Japanese youth whom I interviewed for this study, who worried that they may be impelled by authorities to forfeit one or more of their nationalities on their next trip to Japan.

\section{THE LOCAL RESPONSE OF MIXED JAPANESE AND JAPANESE COMMUNITIES}

In this section I provide a short overview of how mixed Japanese communities based in Japan have responded to the Nationality Law. As Erin Chung (2010) explains, many "noncitizens" in Japan have created their own public channels to voice opposition to Japan's citizenship policies and, by extension, "the notion that Japan is culturally homogenous" (176). Among these groups, it is important to make special note of Zainichi Koreans, who 
historically have led strong activist movements against the political, social and economic inequities as well as the exclusionary practices that the Japanese state has imposed upon them (Chapman 2008; Chung 2010). ${ }^{8}$

Another group that has pioneered human rights activism for non-Japanese residents is an NPO named 'Citizen's Network for Japanese-Filipino Children' (hereafter, 'CNJFC'). The CNJFC's most notable achievement was its role as agent for Japanese-Filipino children and their family members in a 2008 court case titled 'the Nationality Affirmation Case'. The case is heralded as a landmark lawsuit, as it resulted in reform of the Nationality Law and marked a significant re-evaluation of how nationality is understood in Japan (Suzuki 2010, 42). Anthropologist Nobue Suzuki (2010) conducted extensive fieldwork in the years leading up to the case, which included interviews with the NGOs, activists and plantiffs involved. In her paper, she argues that the numerous lawsuits fought by foreign mothers, including Korean and Filipino women, against the Nationality Law during the 1990s and early 2000s ultimately had a positive impact on the 2008 victory for Japanese-Filipino children (Suzuki 2010). The numerous reasons why foreign mothers fought for their children's rights to Japanese nationality are detailed further in Suzuki's (2010) work; however, for mothers of Japanese-Filipino children, the most common drivers were "the uncertainty from their citizenships, identities and future, as well as...other problems, such as the stigma from fatherlessness and poverty" (2010, 36). The Nationality Affirmation Case resulted in an amendment to allow Japanese nationality to a child born out of wedlock to a Japanese father and a foreign mother, thereby also allowing them Japanese citizenship (Chung and Kim 2012; Hara 2018). ${ }^{9}$ The Nationality Affirmation Case was not only symbolic of a rare event where non-Japanese successfully contested the Japanese policy of jus sanguinis (Hara 2018), but Chung and Kim (2012) also argue that it showed how minority multiethnic communities are problematising the notion of an ethnically homogenous Japan.

Japan-based academic research into the Nationality Law has brought to light local opinions of the law and how it has affected multiethnic communities in Japan. In 2005, Michi Takeda conducted a survey involving the 328 members of the Association of Multicultural Families (国際結婚を考える 会), an organisation started by seven Japanese women in 1980 to campaign for the civil rights of multicultural couples and to protest against aspects of the Nationality Law. The survey found that around $70 \%$ of the dual national "children" surveyed hoped to maintain both of their nationalities for future residency and employment opportunities (Takeda 2005, 7).${ }^{10}$ More recently, 
the Japanese newspaper Mainichi Shinbun reported that in an online survey led by Sasaki Teru of Aomori Public University in February 2019, over half of those surveyed said that they saw no issue with foreign nationals applying for Japanese nationality (Wada 2019), suggesting potential public approval for dual nationality in Japan. At the time of writing, activists including the Association of Multicultural Families are running a petition to change the Nationality Law to allow individuals to maintain their dual nationality status (Association for Multicultural Families n.d.). However, it is important to note that the focus of activism by foreign and mixed Japanese nationals is not limited to the Nationality Law: recently, three female activists based in Tokyo-Chung Woohi, Amy Tiffany Loo and Yuka Hamanaka-launched a campaign for non-Japanese nationals' suffrage in Japan (Fitzpatrick 2019).

Prior research shows that the choice of forfeiting a nationality not only affects future choices related to living and employment for dual nationals, but it also strongly affects their idea of identity (Takeda 2008; Hara 2018). As a former Canadian-Japanese dual national told an interviewer for the YouTube channel 'Asian Boss', "both nationalities were a part of my identity, but because Japanese law makes you choose, I feel like my identity is sort of dismissed" (Should Naomi Osaka 2019). For mixed Japanese in Japan, Japanese nationality is as much a means of securing permanent residency status as it is a symbol of membership to a wider community. Within this context, my research examines the way in which mixed Japanese youth in Australia are navigating the implications of the Nationality Law, and by extension, how they are navigating their own multiethnic and multiracial identities as well.

\section{METHODOLOGY}

Using semi-structured interviews, I interviewed 14 participants during the period from June to August 2019. Participants were between the ages of 18 and 24; each was the child of one Japanese and one non-Japanese parent, and all were living in Australia at the time. All participants were either tertiary students or graduates who were either unemployed full-time students, full time students with part-time positions, or full-time workers who had recently graduated. Their parents' employment status varied, and included blue collar and white collar positions such as builders, business owners and teachers, as well as stay-at-home mothers and retired persons. Four interviews were conducted via e-mail and ten interviews were conducted in person at The University of Queensland, St. Lucia campus. All interviews were conducted in English with some Japanese also used. To maintain participant anonymity, pseudonyms are used in place of real names throughout this article. Followup interviews were conducted via e-mail where clarification or further explanation was needed. The recruitment process involved displaying advertisements around the St. Lucia campus, as well as advertising and snowball sampling through the membership and social media channels of UQ WASABI (The University of Queensland's Japanese Language and Culture Society for students), as well as The Japan Foundation, Sydney and The Japanese Society of the Gold Coast. ${ }^{11}$

11 As of October 21st, 2019, UQ WASABI’s name was changed to ‘UQ Japan Exchange’ (UQJX or 日本交流会). 
An overview of basic demographic information of participants, including age, country of birth, parental nationalities and self-described cultural background, is provided in Table 1 . As evidenced by the table, the majority of respondents were the child of a Japanese mother and an Australian father, which provided fertile ground for a comparative analysis across participants who shared commonalities but articulated different cultural identities. The column titled 'Citizenship to Forfeit' lists participant responses to a scenario where they were asked to choose which citizenship they would hypothetically forfeit if required to do so, as further discussed in my analysis below. In this column, N/A (not applicable) is used for participants who were ineligible to answer the scenario as they were not dual citizens at the time of the interview. I have also included participants' self-descriptions of their cultural backgrounds in Table 1 to illustrate that despite commonalities such as parents' nationalities or place of birth, participants' responses suggested diversity in their self-described cultural backgrounds and the expressions of their mixed identities.

Table 1: General Participant Findings

\begin{tabular}{|c|c|c|c|c|c|c|}
\hline Name & Citizenship & $\begin{array}{l}\text { Citizenship } \\
\text { to Forfeit }\end{array}$ & $\begin{array}{l}\text { Parents' } \\
\text { Nationality }\end{array}$ & Age & $\begin{array}{l}\text { Country } \\
\text { of Birth }\end{array}$ & $\begin{array}{l}\text { Cultural Background } \\
\text { (Self-described) }\end{array}$ \\
\hline Mike & AUS \& JPN & AUS & $\begin{array}{l}M=J P N \\
F=A \cup S\end{array}$ & 20 & JPN & Unsure \\
\hline Anastasia & AUS \& JPN & AUS & $\begin{array}{l}M=J P N \\
F=A \cup S\end{array}$ & 23 & AUS & Half Japanese, half Australian \\
\hline Luke & AUS \& JPN & AUS & $\begin{array}{l}M=J P N \\
F=A \cup S\end{array}$ & 21 & AUS & More Japanese than Australian \\
\hline Veronica & AUS \& JPN & JPN & $\begin{array}{l}M=J P N \\
F=A \cup S\end{array}$ & 21 & AUS & $\begin{array}{l}\text { Mixed background-Japanese or } \\
\text { Australian identification depends } \\
\text { on the situation and location }\end{array}$ \\
\hline Jun & AUS \& JPN & JPN & $\begin{array}{l}M=J P N \\
F=A \cup S\end{array}$ & 23 & JPN & A mix of Japanese and Australian \\
\hline Isaac & AUS \& JPN & JPN & $\begin{array}{l}M=J P N \\
F=A \cup S\end{array}$ & 20 & JPN & $\begin{array}{l}\text { Japanese Mother and an } \\
\text { Australian Father, and from Cairns }\end{array}$ \\
\hline Jenny & AUS \& JPN & JPN & $\begin{array}{l}M=J P N \\
F=A U S\end{array}$ & 21 & AUS & $\begin{array}{l}\text { Japanese mother and an } \\
\text { Australian father but born and } \\
\text { raised in Australia }\end{array}$ \\
\hline Soma & AUS \& JPN & JPN & $\begin{array}{l}M=J P N \\
F=A U S\end{array}$ & 22 & JPN & $\begin{array}{l}\text { Mostly Australian with aspects of } \\
\text { Japanese }\end{array}$ \\
\hline Ren & AUS \& JPN & Keep both & $\begin{array}{l}M=J P N \\
F=A \cup S\end{array}$ & 22 & AUS & Half Japanese, half Australian \\
\hline Daichi & AUS \& JPN & Keep both & $\begin{array}{l}M=J P N \\
F=A \cup S\end{array}$ & 22 & JPN & $\begin{array}{l}\text { A mix between Australian and } \\
\text { Japanese }\end{array}$ \\
\hline Yui & AUS & Unsure & $\begin{array}{l}M=J P N \\
F=I R A N I A N\end{array}$ & 19 & AUS & $\begin{array}{l}\text { Persian/Iranian (Dad) and } \\
\text { Japanese (Mum) }\end{array}$ \\
\hline Lilly & AUS & $\mathrm{N} / \mathrm{A}$ & $\begin{array}{l}M=J P N \\
F=I T A L I A N\end{array}$ & 19 & AUS & $\begin{array}{l}\text { Australian with a Japanese and } \\
\text { Italian ethnic background. }\end{array}$ \\
\hline Mary & AUS & N/A & $\begin{array}{l}M=J P N \\
F=A U S / I R E\end{array}$ & 21 & AUS & $\begin{array}{l}\text { An Australian influenced by a } \\
\text { Japanese upbringing }\end{array}$ \\
\hline Hiro & AUS & N/A & $\begin{array}{l}M=T W N \\
F=J P N\end{array}$ & 19 & AUS & $\begin{array}{l}\text { "A blur between all } 3 \text { cultures" } \\
\text { (Australia, Japan, Taiwan) }\end{array}$ \\
\hline
\end{tabular}


In my analysis of the interview data collected, I apply Pierre Bourdieu's (1986) theory of cultural capital to help visualise the invisible skills and knowledge that mixed Japanese youth hold. Erik Neveu (2018) summarises cultural capital clearly and concisely as follows.

Cultural capital is made of knowledge and know-how, of the skills and analytical tools that allow one to manage and produce social relations, cultural products, and technical devices.

(Neveu 2018, 5)

Neveu's definition emphasises the intangible nature of cultural capital, as well as its role in yielding profit for its owner. In applying this definition, examples of cultural capital held by mixed Japanese youth in Australia may include their cross-cultural knowledge of Australia and Japan, their knowledge of expected behaviours in different cultural environments, and their bilingualism. Furthermore, their cultural capital may also be seen as either Japanese capital or Australian capital. For example, Japanese capital may include their Japanese language ability or knowledge of expected behaviours within Japanese contexts.

However, Neveu (2018) argues that the above definition falls short of noting several other aspects of cultural capital that I have found to be applicable to my findings. As Bourdieu (1986) explains, cultural capital holds a "scarcity value"; in other words, the rarer the capital is, the higher its value becomes (246). As such, competition may follow between holders of certain forms of cultural capital (Neveu 2018). Additionally, cultural capital requires an active investment of time, such as in learning a new language or gaining new knowledge, in order to be effective (Bourdieu 1986). Finally, the yields of cultural capital are relative to the "social situation" in which the capital is implemented (Neveu 2018, 1). Bourdieu (1986) uses an example of a person who is "able to read in a world of illiterates" to emphasise how scarcity value and social context control the value of cultural capital (245).

I have applied Bourdieu's (1986) concept of cultural capital throughout my analysis below to better understand the ways in which mixed Japanese youth actively invest in their cultural capital and implement it in their professional spheres to produce more favourable economic outcomes. After conducting a discourse analysis of participant responses, I found that four dimensions of cultural capital as discussed above were pertinent to the participants of this study: scarcity value, social relativity, time investment and intangibility. By applying these dimensions of cultural capital to my analysis, I aim to visualise how mixed Japanese youth in Australia implement their cultural capital in a professional capacity. Additionally, I will use Bourdieu's (1986) concept to examine how the participants align their cultural capital with their citizenship status to achieve professional and personal goals. 


\section{DISCUSSION}

\section{Forfeiting Citizenship}

Of the 14 participants in the study, three held Australian citizenship only and 11 held both Japanese and Australian citizenship. Of the 11 dual citizens who participated, five were 22 years or older and six were 21 or under. All five participants who were aged 22 and above, and were thereby past the age limit for dual citizenship under Japanese law, were dual citizens at the time. All five stated that they would attempt to maintain their dual citizenship status for as long as possible. To do so, pre-emptively and prior to turning 22, participants had renewed their Japanese passport in Australia for the maximum length of 10 years. No participants had been through the process of forfeiting one of their nationalities.

Most participants knew of the Nationality Law through their Japanese parent, friends or their own research on the internet. Upon asking participants about their knowledge of the law, I found that 8 of the 11 dual national respondents either did not know anything of the law or held incorrect knowledge of the law due to the second-hand nature of the information they had received. For example, some respondents believed the age of forfeiting to be 20 or 21 instead of 22. A survey conducted by Takeda (2005) in Japan found that $37 \%$ of young dual national respondents stated that they knew nothing of the law (7). In 2008, Takeda conducted the survey again for dual nationals outside of Japan, such as in Austria, Nepal and other countries, and found that $45.5 \%$ of respondents answered that they did not have any knowledge of the law (26). Although the smaller sample of my study presents a higher percentage (73\%) of respondents without accurate knowledge of the law, Takeda's study similarly draws attention to the surprising number of dual nationals inside and outside of Japan who are unaware of the details of the Nationality Law.

Many participants in my study presented a view of the Nationality Law that greatly contrasted with the opinions of mixed Japanese communities in Japan, such as the aforementioned Association for Multicultural Families which sees the Nationality Law as in need of revision. Participants believed the Nationality Law was just insofar as it aligned with their presumed understanding of a historically "nationalistic" Japanese government (Luke 2019). As Luke states, "I can respect why [the Nationality Law exists] because Japan has had a history of closing off borders and...[it's] very nationalistic". However, not all participants thought this way:

I think that the [Japanese Nationality] Act may be outdated, especially with Japan adopting a more global lens and more people from around the world travelling/visiting/living/taking interest in Japan. Yes, it would be awesome if the Act was changed.

(Yui 2019)

As Yui's comment above illustrates, some also saw the law as representing an unfair and outdated approach to citizenship, and being contra to Japan's 
soft power expansion, its role as a global leader and its many globalisation projects, such as Cool Japan or the (now postponed) 2020 Olympics. ${ }^{12}$

I asked participants to tell me which citizenship they would hypothetically forfeit if they were put into a situation where they were forced to forfeit one. As shown in Figure 1, three participants said that they would choose to forfeit their Australian citizenship, five would forfeit their Japanese citizenship, two would try to keep both, and one was undecided. Participants answered with a variety of responses that reflected varying perceptions of what citizenship means, and varying concepts of the relationship between citizenship status and identity. The three participants without Japanese nationality at the time of interview were tallied as N/A, as the question was not applicable. The following section of my analysis will explore the reasons behind the participants' response to the question, and the extent to which they believe that forfeiting their citizenship would result in forfeiting their identity.

Figure 1: Participant answers to "Which citizenship would you forfeit?"

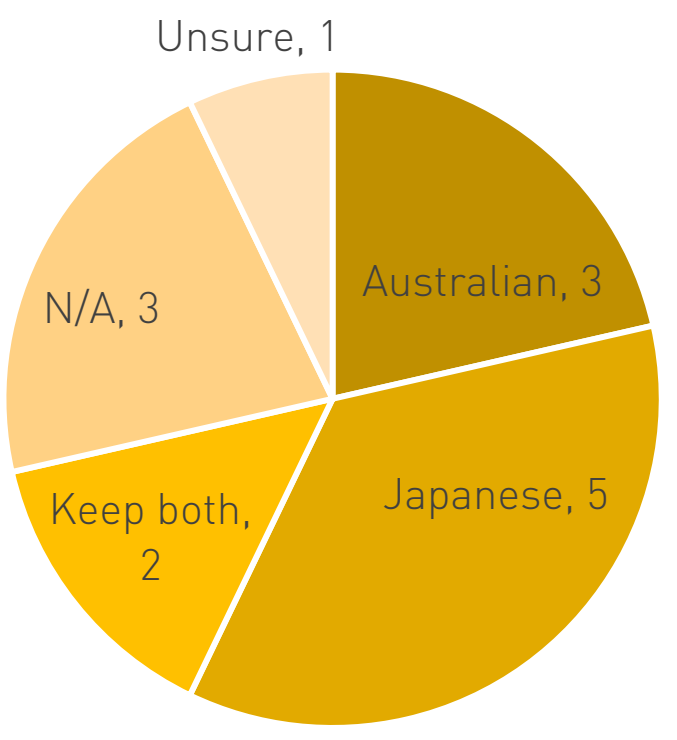

\section{Forfeiting Japanese Citizenship}

When responding to the hypothetical question of which citizenship they would forfeit if necessary, the majority of participants suggested that they would forfeit their Japanese citizenship. The reasons for this response varied. The data indicated that several participants would forfeit their Japanese citizenship because they have no plans to live in Japan or stay in Japan for an extended period in future.

I'm not too fussed about being a Japanese citizen to be honest, but I think mum really wants me to have a foot in the door, like if she wants to go back to Japan like I can't help her because I'm not a Japanese citizen...[But] I'm not too fussed about it and I don't plan to live the rest of my life in Japan, like it would be cool but I don't plan to.

(Jenny 2018) 
Like Jenny, other participants also noted that their Japanese parent wanted them to keep their Japanese citizenship in case they needed to return to Japan for an extended period in future. However, many countered their parent's argument by explaining that they already enjoy a high level of mobility between Japan and Australia as they are able to travel to Japan from Australia on the three-month Japanese tourist visa. The data also showed that those who said they would forfeit their Japanese citizenship often justified the decision with the rationalisation that they would not be able to contribute to Japanese society or participate in Japanese politics as a Japanese citizen, such as by voting in Japanese elections, as they are not knowledgeable enough of the Japanese social, political and economic landscapes to make informed political decisions. In other words, participants perceived themselves as lacking an adequate amount of Japanese capital to perform civic duties in Japan. This perspective neglects that fact that, unlike in Australia, voting in elections is not compulsory in Japan. More significantly, however, it correlates with Morris-Suzuki's (2015) thesis that understandings of nationality (kokuseki) are often conflated with the duties of a citizen, or 'shimin' (市民), within the anglophone context.

Participants also stated that they would maintain Australian citizenship to take advantage of educational initiatives that they would only have access to as Australian citizens, such as the Australian HECS (Higher Education Contribution Scheme) system, or the Japanese MEXT (Ministry of Education, Culture, Sports, Science, and Technology) scholarship, which is only available to non-Japanese citizens. As a 2018 roundtable on student mobility highlighted, Japan continues to maintain a position as an attractive overseas study destination for Australian students in tertiary education (The Japan Foundation, Sydney 2019). This marks just one of the examples that demonstrates how mixed Japanese youth align their citizenship status and their cultural capital to realise professional outcomes.

In addition to economic reasons, participants suggested that they would consider other personal reasons such as their friendship networks or their mixed identities when making decisions around forfeiting citizenship. Participants who said that they would forfeit their Japanese citizenship were those who demonstrated throughout the interview that they held a closer connection to their Australian identities and a feeling of belonging in Australia, rather than Japan. For example, Jenny stated she would choose Australian citizenship because she lives in Australia and plans to continue her studies in Australia. Similarly, Daiichi (2019) explained that he would not want to give up his Australian citizenship to "avoid breaking a lot of ties that [he has] slowly built over a long time in Australia". Jun shared a similar sentiment, as she has established a life in Australia and feels it would be better to forfeit her Japanese citizenship.

I feel like it's a shame that I can't say that I am both Japanese and Australian, but I also feel like I've planned and had my life in Australia for most of the time, so it almost seems unfair to then want something else as well. I guess because I have family and some friends still in Japan that I'm close to, I feel like I still have a valid enough connection without that. I guess then again 
having an Australian passport I can go to Japan so easily as well, it's easy to travel. It would be nice to have both, but it doesn't really add anything to me. (Jun 2019)

A close reading of her comment reveals that Jun feels she would still enjoy the same travel benefits that she has as a dual citizen, even if she forfeited her Japanese passport. This contrasts with the situation of many other mixed Japanese youth who are at a similar life stage to the participants in my study, such as Japanese Filipinos (see Hara 2018) or Japanese Indonesians (see Suzuki 2011), for whom the decision to forfeit their Japanese citizenship becomes difficult when they consider the economic and political stability of The Philippines or Indonesia. ${ }^{13}$ For example, two Japanese Filipinos who were born and raised in The Philippines were interviewed by Megumi Hara (2018) in The Philippines and Japan between 2008 and 2015. The participants spoke of "their motivation to acquire Japanese nationality" after new allowances to Japanese Nationality acquisition were granted following the 2008 Nationality Affirmation Case, as discussed above (170). Notably, attractive economic prospects such as a higher salary and stable socioeconomic conditions were the main motivations behind their desire to acquire Japanese nationality, which both eventually achieved, thereafter settling permanently in Japan (170). My data supports Hara's (2018) hypothesis that "the impact of obtaining Japanese nationality differs [according to] the parents' country of origin and socioeconomic settings" (159). This is exemplified by the case of Jun, who enjoys relative political and economic stability in both countries (Australia and Japan), and is thus at less of an impasse when contemplating forfeiting one of her citizenships.

\section{Forfeiting Australian Citizenship}

The results thus far suggest that participants perceive a strong relationship between their citizenship status, economic futures, mobility across borders and identity. However, several participants stated that they felt their citizenship status was unrelated to their identity as a mixed Japanese. For example, when asked if he would want to keep his Australian citizenship, Luke responded:

Not really. Like I said, I'd rather keep it if I could but, Japan doesn't allow it so it's just the way it is, so there's no point in being upset about it...I don't feel like I am as Australian anymore. So, I wouldn't be too disappointed. I mean, it's not like it's gonna change me in any way. I am still who I am, but... it won't affect me too much I think.

(Luke 2019)

In the quote above, it is evident that Luke's hypothetical decision to forfeit his Australian citizenship is informed by a feeling of disconnection from his Australian identity. All three participants who suggested that they would forfeit their Australian citizenship expressed a strong connection with their Japanese identities and feelings of belonging towards Japan. Further, they all 
showed an interest in working and living in Japan in the future. They also cited the value of the Japanese passport as a factor in their decision, as the Japanese passport was ranked as the most powerful passport in the world in 2019 and 2020 by the Henley Passport Index (Adams 2019). ${ }^{14}$

Luke (2019) makes a point of asserting that his choice of citizenship would not affect who he is: "I am still who I am". Other participants also felt that their citizenship status does not define the parameters of their identity, such as Jun (2019), who chose to hypothetically forfeit her Japanese citizenship:

When I was younger it felt like a bigger deal, but to me because I feel much more comfortable with who I am, that's just a piece of paper. Like I know who I am, I guess?

(Jun 2019)

Like Jun, several participants suggested that forfeiting one of their citizenships would not result in a loss of a sense of identity. Additionally, when describing their identities, many participants first referred to factors such as family, friends, hobbies and careers, which they perceived as more influential than their citizenship status. This finding correlates with emerging mixed Japanese identity studies literature (Shimoji-Lawrence 2018; Keane 2018) which has gestured towards the benefits of exploring a range of identity indices beyond nationality, such as gender, phenotype, environment and, importantly, language.

\section{Forfeiting Identity}

As illustrated above, participants such as Luke and Jun asserted that their citizenship status was not an indicator of their identities. Some, however, valued citizenship as a representation of their ethnicity and as an index of their mixed identity:

I'm kind of annoyed because I don't want to have to choose, I want both. But then, I do understand... why they're so strict. I don't wanna lose either, I am both Australian and Japanese so why do I have to choose what passport?

(Anastasia 2019)

As Anastasia's frustration highlights, the Nationality Law poses a challenge for multiethnic and multiracial outliers and their mixed identities. One of the dominant challenges for mixed Japanese youth in Australia is the struggle to maintain a cultural balance between engagement with their Japanese and Australian capital. This corroborates findings from the long-term study presented in Pollock and van Reken's (2009) book titled Third Culture Kids, which included participants from a range of cultural backgrounds and ages including mixed Japanese persons. ${ }^{15}$ Pollock and van Reken (2009) found 
that 'Third Culture Kids' often struggle to maintain a balance between the cultures they are invested in, such as their parents' cultures and the cultural environment they are raised in. Participants in my study evidenced similar fears of losing connection to their cultural background or identity, which often manifested as a fear of losing their Japanese language proficiency.

For some mixed Japanese in Australia, Japan's Nationality Law threatens to further disconnect them from one of their cultural backgrounds and is seen as a symbolic refusal to acknowledge their identities as mixed Japanese Australians. On the other hand, some participants in my study questioned their right to Japanese nationality:

I believe that it is pretty in line with what I know and have experienced of Japanese culture. Japan is a very patriotic country and it is difficult to be accepted in Japanese society unless you are fully Japanese. Even as a half Japanese person, I believe retaining my Japanese citizenship would not really make me 'Japanese' and so while I would like to live there for a short time, I could not make full use of my citizenship and live there for the majority of my life.

(Veronica 2019)

Like Veronica, some participants felt that even if they retained their dual citizenship, they would never be truly acknowledged as Japanese nationals in Japan due to the range of other factors influencing their socially perceived identities, such as phenotype or language use. As past research has suggested, Japan maintains a strong 'foreigner vs. Japanese' binary that has permeated its institutions and society (e.g., Burgess 2004; Lee and Tanaka 2007; ShimojiLawrence 2018). Like Veronica, many participants in this study voiced a desire to maintain dual citizenship status. However, Veronica is keenly aware that her Japanese citizenship (or in actuality, her kokuseki) may not be enough to ensure that she is socially accepted as Japanese by others in Japan, as there remain other contradictory social indices of identity that operate against her, such as her phenotype and her Japanese language proficiency.

For participants who feel their identities are closer to one side-either Japanese or Australian - the hypothetical decision to forfeit the comparatively more distant citizenship, and by extension any sense of identity linked to this citizenship, was evidently easier. For example, as Luke (2019) stated above, “I don't feel like I am as Australian anymore. So, I wouldn't be too disappointed." This rationale can be similarly found in the results of Suzuki's 2011 study involving participants of mixed Japanese-Indonesian heritage. In her study, one participant stated that they would forfeit their Indonesian citizenship because they do not want to be Indonesian; rather, they want to be acknowledged as Japanese through the official status of nationality (Suzuki 2011, 81).

\section{A Strategic Alignment of Citizenship and Cultural Capital}

Whilst the relationship between identity and citizenship varies for each participant, I have found an overarching commonality in their approach 
towards citizenship. Mixed Japanese youth are strategically aligning their choice of citizenship with considerations of cultural capital and perceived future career outcomes. This is a trend that has surfaced in similar studies over the past decade (Hara 2018; Suzuki 2011), supporting Ong's (1999) argument that in the age of capitalism and globalisation, individuals are "fluidly and opportunistically" using their citizenship to achieve socioeconomic mobility and prestige (6).

To illustrate how mixed Japanese youth in Australia are repositioning their cultural capital within cross-cultural contexts, I will first draw upon Mike's experiences working for an Australian marketing company in Japan. Mike explains his role in helping the company expand into the Japanese consumer market:

[Whilst living in Japan] I...started off doing social media and then went off into...the actual distribution places and then started up doing...Japanese retail marketing and helping out over there [in Australia] ...'cause I have that perspective of the Japanese audience and I can relate to how they do it and stuff.

(Mike 2019)

In the example above, Mike's cultural capital is identified as his "perspective of the Japanese audience" and knowledge of Japanese and Australian marketing practices. This qualifies as cultural capital because it is embodied cultural knowledge that derives from his own experiences living in Japan and Australia. Mike is therefore taking advantage of his cultural capital-i.e., his knowledge of Japanese and Australian consumers-to produce marketing materials that effectively communicate between Australia (the company) and Japan (the consumer).

Another example of a participant who strategically aligned their cultural capital with their future career was Jenny:

That was kind of a dream for me to do, like have a private practice for Japanese people and Japanese families...in the [Australian] community [...]. I think [Japanese-specialised healthcare] would be a bit more...not heartwarming, but a bit more anshin, like a bit more secure [to have] someone [look after you] who kind of understands those Japanese values.

(Jenny 2019)

Jenny (2019) envisions a potential future career where she can apply her knowledge of the Japanese healthcare system and "Japanese values" to her own private Japanese medical practice in Australia. Jenny explained to me that through her experience working in the field, she had identified a gap in the market for medical care delivered by people who are familiar with Japanese customs and can speak Japanese. In other words, the combination of her Japanese capital and medical training is a highly valued and scarce resource. In the quote above, Jenny's choice of the word 'anshin' (安心; 'relief', or 'peace of mind') when describing the Japanese style of service that she hopes to deliver in Australia is evidence of her Japanese capital, and emphasises her capability of fluidly moving between different cultural spaces to create culturally specific meaning within a new self-conceptualised career path. 
Soma's experience working at a ski field in Japan is another example of the scarcity value of cultural capital that mixed Japanese youth hold. Soma explained to me that he secured his position at the ski field by sending a short message to the company via Facebook. The ease with which he secured the position reflects the scarcity of his capital (namely, his bilingualism), and the resulting lack of competition experienced by people with his capabilities in the industry. As shown in the quote below, Soma's cultural capital becomes further profitable in combination with his dual citizenship status:

There was like a very strong Australian working group there [at the ski fields]. [...] Most people do two...seasons. Because you can get a [Japanese] working visa for one year and [immigration] extend it for another year, and you have...people who go over there every year like business owners, and everyone there has... a sense of the Japanese culture and like a respect for it. Good thing with me is I actually have a Japanese passport as well, so I can... go as many times as I want.

(Soma 2019)

Soma's account shows how he uses his Japanese and Australian capital at the ski field to communicate effectively between Australian and Japanese co-workers and customers. The quote above importantly highlights Soma's realisation of the economic benefits of maintaining Japanese-Australian dual citizenship, as he can work in Japan without restrictions, unlike his Australian co-workers who must apply for visas. Maintaining dual citizenship status means that participants like Soma, Jenny and Mike can visualise careers that are mobile and communicate between Japan and Australia, while implementing and improving their valuable cultural capital in order to do so.

\section{CONCLUSION}

This paper arrives at an interesting and turbulent moment in Japanese history. The Japanese government is currently striving to maintain the myth of Japanese ethnic homogeneity whilst also urgently injecting necessary foreign labour into a receding Japanese economy. As a result, its legal and social systems are struggling to adapt to the circumstances of an increasing number of mixed Japanese persons, as well as Japan's new and old foreign residents. This is demonstrated by the ambiguities of Japan's Nationality Law, which-despite stipulating a 'one person, one nationality' guideline for mixed Japanese-has allowed some mixed Japanese youth in Australia to retain their dual citizenship status. Some have enjoyed benefits from doing so, by applying for tertiary education scholarships and schemes, for example, and maintaining a high level of mobility between Australia and Japan. As discussed, the participants in this study, who have enjoyed these kinds of benefits and are active in their careers or tertiary study, have strategically aligned their cultural capital to envision or realise cross-cultural careers that communicate between Japan and Australia.

When faced with the hypothetical scenario of being forced to forfeit one citizenship, some participants stated that intangible factors such as feelings of belonging, personal history, relationships and identity would play a role in mo 
their decision-making. The scenario also led some to question the legitimacy of their claim to Japanese nationality and the purpose of the Nationality Law. Ultimately, however, most respondents perceived citizenship as little more than an official title that does not affect their sense of identity. My findings therefore indicate that mixed Japanese youth in Australia primarily equate citizenship with economic value, rather than identity value.

To the best of my knowledge, this is the first publicly available study on mixed Japanese youth in Australia and their perceptions of dual nationality. While the study is limited by the small sample size and requires a larger-scale project to confirm its findings, it nonetheless highlights similarities that mixed Japanese youth in Australia share with mixed Japanese youth in other countries. For example, the work of Hara (2018) in The Philippines and Suzuki's (2011) work in Indonesia has similarly demonstrated that mixed Japanese place significant value upon socioeconomic opportunities and future careers when deciding which nationality (if any) they will forfeit.

Conversely, my study also presents findings that differ from those found in scholarship on mixed Japanese youth outside of Japan and Australia. For mixed Japanese youth in developing countries such as The Philippines and Indonesia, Japanese citizenship implies a guaranteed higher wage, a politically and socially stable environment and higher standards of living. On the contrary, evidence from my study suggests that the consequences of forfeiting citizenship for mixed Japanese youth in Australia are more closely aligned with perceived future career opportunities. I speculate that this may be because of the current strong relationship between Asia and Australia's education sectors, which has led to an increased number of opportunities for study abroad exchange and internship programs, thereby increasing the appeal of working overseas. Further research is required to determine why youth predominantly value citizenship and/or nationality as a determinant of socioeconomic opportunity.

The majority of mixed Japanese youth I interviewed held unreliable knowledge of the Nationality Law, and felt that their citizenship status did not hold a strong connection to their identity. This contrasts with a growing argument in recent Japanese scholarship (e.g., Shimoji-Lawrence 2018; Keane 2018) which asserts that mixed Japanese youth in Japan perceive a strong connection between their nationality and multiethnic identities. This suggests that mixed Japanese youth in the Australian context may already perceive an official and/ or social acceptance of their multiethnic identity which does not need to be further supported by their citizenship status. Building on my study, future research could examine how highly mobile, mixed Japanese youth in Australia (and elsewhere) interpret concepts such as 'citizenship' and 'nationality', particularly now that the global COVID-19 pandemic is reshaping the ways in which we travel, study, work and communicate across borders.

\section{GLOSSARY}

chōsen (朝鮮)

lit., the former undivided 'Korea', but a term now often associated with North Korea 
hāfu (ハーフ)

a derivative of the English world 'half'; used in Japan to refer to Japanese persons of mixed race and/or ethnicity

jus sanguinis

'right of blood'; citizenship or nationality as determined by the nationality or ethnicity of one or both parents

jus soli

'right of soil'; citizenship or nationality as determined by birth within the territory of a state

kokuseki (国籍)

nationality

koseki (戸籍)

Japan's family registry system (or someone's lineage as registered therein)

nihonjinron (日本人論)

lit., 'theories about the Japanese people'; a genre of academic and popular literature which explores Japanese national and cultural identity

$\operatorname{shimin}($ 市民)

citizen

shiminken (市民権)

citizenship

tan'itsu minzoku (単一民族)

lit., 'single peoples' or 'single ethnicity'; used by scholars to refer to the myth of Japanese ethnic homogeneity

zainichi (在日)

lit., 'resident of Japan'; commonly used to refer to long-term Korean residents of Japan and their descendants

\section{APPENDIX: LIST OF INTERVIEWS}

Yui [pseud.]. 2019. Interview by author. Digital recording in English and e-mail interview. August 5.

Mike [pseud]. 2019. Interview by author. Digital recording in English. July 31.

Soma [pseud]. 2019. Interview by author. Digital recording in English. July 30.

Jenny [pseud]. 2019. Interview by author. Digital recording in English. July 29.

Luke [pseud]. 2019. Interview by author. Digital recording in English. June 18.

Jun [pseud]. 2019. Interview by author. Digital recording in English. June 18.

Anastasia [pseud]. 2019. Interview by author. Digital recording in English. June 10.

Daiichi [pseud]. 2019. Interview by author. E-mail interview. June 6.

Veronica [pseud]. 2019. Interview by author. E-mail interview. June 5.

\section{REFERENCES}

Adams, C. 2019. "Japanese Passport Ranked the Most Powerful in the World.” The Independent, 8 January. Accessed 8 July, 2019. https://www.independent. 
co.uk/travel/news-and-advice/worlds-most-powerful-passports-japansingapore-south-korea-visa-free-travel-a8716796.html.

Association for Multicultural Families [国際結婚を考える会]. n.d. Appeal for Signing. Accessed 14 November, 2019. http://amf.world.coocan.jp/pdf/shomeionegai\%20English.pdf.

Bourdieu, P. 1986. “The Forms of Capital." In Handbook of Theory and Research for the Sociology of Education, edited by J. G. Richardson, 241-58. New York: Greenwood Press.

Burgess, C. 2004. "Maintaining Identities: Discourses of Homogeneity in a Rapidly Globalizing Japan." Electronic Journal of Contemporary Japanese Studies. Accessed 14 November, 2019. https://www.japanesestudies.org.uk/articles/ Burgess.html.

. 2015. “To Globalise or Not to Globalise? 'Inward-looking Youth' as Scapegoats for Japan's Failure to Secure and Cultivate 'Global Human Resources'." Globalisation, Societies and Education 13 (4): 487-507. https:// doi.org/10.1080/14767724.2014.966805.

. 2018 "US Open Winner Naomi Osaka: Japanese or Not Japanese?" [blogpost]. A British Prof. in Japan, 21 September. Accessed 14 November, 2019. https://abritishprofinjapan.blogspot.com/2018/09/naomi-osakajapanese-identity.html.

Chapman, D. 2008. Zainichi Korean Identity and Ethnicity. Abingdon: Routledge. https://doi.org/10.4324/9780203944813.

2019. “Article 772 and Japan’s Unregistered.” Japan Forum 31 (2): 235-53. https://doi.org/10.1080/09555803.2018.1461676.

Chung, E. A. 2010. Immigration and Citizenship in Japan. Cambridge: Cambridge University Press. https://doi.org/10.1017/CBO9780511711855.

Chung, E. A., and D. Kim. 2012. "Citizenship and Marriage in a Globalizing World: Multicultural Families and Monocultural Nationality Laws in Korea and Japan." Indiana Journal of Global Legal Studies 19 (1): 195-219. https:// doi.org/10.2979/indjglolegstu.19.1.195.

Fitzpatrick, J. 2019. "Muted in Country of Birth, Three Women Fight for Voice and Choice in Japan." The Japan Times, 2 September. Accessed 5 September, 2019. https://www.japantimes.co.jp/news/2019/09/02/national/social-issues/ women-fight-for-voice-and-choice-in-japan/.

Gottlieb, N. 2012. "Language, Citizenship and Identity in Japan." In Language and Citizenship in Japan, edited by N. Gottlieb, 1-18. New York: Routledge. https://doi.org/10.4324/9780203144442.

Green, D. 2013. "Local Foreign Suffrage in Kawasaki City: The Changing State of Voting Rights in Japan." Electronic Journal of Contemporary Japanese Studies 1 (6). Accessed 3 March, 2020. http://www.japanesestudies.org.uk/ejcjs/ vol13/iss1/green.html. 
Hara, M. 2018. "Rethinking Nationality Issues of Japanese-Filipinos from the Perspective of NGOs and Youth." In Thinking Beyond the State: Migration, Integration, and Citizenship in Japan and the Philippines, edited by J. Zulueta, 157-86. Eastbourne, UK: Sussex Academic Press.

Henley Passport Index. n.d. Henley Passport Index. Accessed 7 March, 2020. https:// www.henleypassportindex.com/passport. https://doi.org/10.7765/97815261 47295.00035.

Iwase, N. [岩澤 直美]. 2018. “Osaka Naomi senshu wa 'Nihonjin' na no ka [大 阪直美選手は「日本人」なのか].” Huffington Post, 11 September. Accessed 14 September, 2019. https://www.huffingtonpost.jp/naomi-iwazawaa/osakanaomi-20180911_a_23522169/.

Keane, J. [ケイン 樹里安]. 2018. “'Häfu’ no doramaturugi no tame ni-sosharu media, rōdō, jendā chitsujo [ハーフのドラマトゥルギーのために一ソーシャルメディア、労 働、ジェンダー秩序一].” OCU Journal of Sociology 15 (15): 20-38.

Lee, S. I., S. Murphy-Shigematsu and H. Befu., eds. 2006. Japan's Diversity Dilemmas: Ethnicity, Citizenship, and Education. Lincoln, Nebraska: iUniverse Inc.

Lee, S. I. [李 洙任] and H. Tanaka [田中 宏]. 2007. “Gurōbaru jidai no Nihon shakai to kokuseki [グローバル時代の日本社会と国籍].” Tokyo: Akashi Shoten [明石 書店].

Ministry of Justice. [法務省]. n.d.[a]. Kokusekihō [国籍法]. Accessed 14 November, 2019. http://www.moj.go.jp/MINJI/kokusekiho.html.

.n.d.[b]. The Choice of Nationality. Accessed 1 November, 2019. http://www. moj.go.jp/content/001206753.pdf.

Morris-Suzuki, T. 2015. "Beyond Racism: Semi-Citizenship and Marginality in Modern Japan.” Japanese Studies 35 (1): 67-84. Accessed 4 January, 2020. https://doi.org/10.1080/10371397.2015.1014469.

Murakami, S., and C. Baird. 2018. “Dual Citizenship in Japan: A “Don’t Ask, Don’t Tell” Policy Leaves Many in the Dark." The Japan Times, 18 April. Accessed 18 October, 2019. https://features.japantimes.co.jp/dualcitizenship/.

Murphy-Shigematsu, S. 2000. "Identities of Multiethnic People in Japan." In Japan and Global Migration: Foreign Workers and the Advent of a Multicultural Society, edited by M. Douglass and G. S. Roberts, 196-216. Honolulu, Hawai'i: University of Hawai'i Press.

Neveu, E. 2018. "Bourdieu's Capital(s): Sociologizing an Economic Concept." In The Oxford Handbook of Pierre Bourdieu, edited by T. Medvetz and J. J. Sallaz, 1-10. New York: Oxford University Press. https://doi.org/10. 1093/oxfordhb/9780199357192.013.15.

NHK News [NHK ニュース]. 2019. “Tenisu Ōsaka Naomi senshu 'Nihon daihyō de Tokyo gorin mezasu' Nihon kokuseki sentaku [テニス大阪直美選手「日本代 表で東京五輪目指す」日本国籍選択].” NHK News, 10 October. Accessed 10 October, 2019. https://www3.nhk.or.jp/news/html/20191010/k100121213310 00.html. 
Oguma, E. [小熊 英二]. 1995. Tan'itsu minzoku shinwa no kigen一'Nihonjin' no jigazō no keifu [単一民族神話の起源一「日本人」の自画像の系譜]. Tokyo: Shin’yōsha [新曜社].

O’Hare, M. 2020. “Henley Index: Japan Tops 2020 List of World's Most Powerful Passports.” CNN, 8 January. Accessed 7 March, 2020. https://edition.cnn. $\mathrm{com} /$ travel/article/henley-index-world-best-passport-2020/index.html.

Ong, A. 1999. Flexible Citizenship: The Cultural Logics of Transnationality. USA: Duke University Press.

Pollock, D., and R. van Reken. 2009. Third Culture Kids: Growing Up Among Worlds (3rd edition). Boston: Nicholas Brealey Publishing.

Rich, M. 2018. "In U.S. Open Victory, Naomi Osaka Pushes Japan to Redefine Japanese." The New York Times, 9 September. Accessed 3 March, 2019. https://www.nytimes.com/2018/09/09/world/asia/japan-naomi-osaka-usopen.html.

Ryang, S. 2008. “The Denationalized Have No Class: The Banishment of Japan's Korean Minority-A POLEMIC." The Asia-Pacific Journal Japan Focus, 6(6): 1-23. Accessed 22 May, 2020. https://apjjf.org/-Sonia-Ryang/2776/ article.html.

Shao-Kobayashi, S. 2019. "Who's Pitiful Now?": Othering and Identity Shifts of Japanese Youth from California to Tokyo." Diaspora, Indigenous, and Minority Education 13 (1): 13-25. https://doi.org/10.1080/15595692.2018. 1438391.

Shimoji-Lawrence, Y. [下地ローレンス 吉孝]. 2018. 'Konketsuji' to 'nihonjin': hāfu, dabburu, mikkusu no shakaishi [「混血児」と「日本人」:ハーフ、ダッブル、ミッ クスの社会史]. Tokyo: Seidosha [青土社].

"Should Naomi Osaka Be A Japanese Or US Citizen? [Street Interview] | ASIAN BOSS." 2019. YouTube video, 4:00, posted by "AsianBoss," February 21. Accessed 4 August, 2019. https://www.youtube.com/watch?v=8O_ AZL4Ca3M\&t=241s.

Smith, D., J. Wykes, S. Jayarajah and T. Fabijanic. 2010. Citizenship in Australia. Canberra: Department of Immigration and Citizenship. Accessed 22 May, 2020. https://www.homeaffairs.gov.au/research-and-stats/files/citizenshipin-australia-2011.pdf.

Söderberg, M. 2011. Changing Power Relations in Northeast Asia: Implications for Relations Between Japan and South Korea. Abingdon: Routledge. https:// doi.org/10.4324/9780203833438.

Song, M., ed. 2003. Choosing Ethnic Identity. Cambridge, UK: Polity Press.

Sugimoto, Y. 1999. "Making Sense of Nihonjinron." Thesis Eleven 57: 81-96. https:// doi.org/10.1177/0725513699057000007.

Suzuki, K. [鈴木 一代]. 2011. "Nikkei kokusai-ji no bunka idō to gengo, bunka, bunkateki aidentiti [日系国際児の文化移動と言語、文化、文化的アイデンティティ].” 
Saitama Gakuen Daigaku kiyō [埼玉学園大学紀要], 11: 75-88. https://doi. org/10.5509/201083131.

Suzuki, N. 2010. "Outlawed Children: Japanese Filipino Children, Legal Defiance and Ambivalent Citizenships." Pacific Affairs 83 (1): 31-50. https:// doi.org/10.5509/201083131.

Takeda, M. [竹田 美知]. 2005. “Kokusai kekkon kara umareta kodomo no kokuseki sentaku to sono eikyō yōin-kokusai kekkon wo kangaeru kai no bāi [国際 結婚から生まれた子どもの国籍選択とその影響要因 一国際結婚を考える会の 場合一].” Nihon kasei gakkai shi [日本家政学会誌] 56 (1):3-13.

.2008. "Kaigai zaijū no kokusai kekkon kara umareta kodomo no aidentitī keisei ni ataeru eikyō yōin: kokusai kekkon wo kangaeru kai no bāi [海外 在住の国際結婚から生まれた子どものアイデンティティー形成に与える影響要 因: 国際結婚を考える会の場合].” Seikatsu kagaku ronsō [生活科学論叢], 39: 21-33. http://doi.org/10.14946/00001634.

Takeda, S. [武田 里子]. 2018. “Gurōbaru-ka jidai no 'kokueki' to fukusū kokuseki no zehi wo megutte [グローバル化時代の「国益」と複数国籍の是非をめぐつて].” Kokusai chīkigaku kenkyu [国際地域学研究] 21: 35-50.

Takeshita, S. 2019. "Mixed Children in Japan: From the Perspective of Passing." Asian Ethnicity. 21 (2): 320-36. https://doi.org/10.1080/14631369.2019. 1639132.

The Japan Foundation, Sydney. 2019. Roundtable Report, Asia-Informed Student Mobility in the Indo-Pacific Era: Case Studies from Japan. Discussion held at Asian Studies Association of Australia (ASAA) Conference, Sydney, 2018. Sydney: The Japan Foundation, Sydney. Accessed 14 November, 2019. https:// jpf.org.au/jpf/jpfmedia/JapanFoundation_Student-Mobility-Roundtable_ Report.pdf.

Törngren, S. O. 2018. "Ethnic Options, Covering and Passing: Multiracial and Multiethnic Identities in Japan." Asian Journal of Social Science, 46: 748-73. https://doi.org/10.1163/15685314-04606007.

Wada, H. 2019. "Sasae-au 'imin jidai' fukusū kokuseki 'kokumin no ukedome wa kanyō' Sasaki Teru Aomori Kōritsu Daigaku kyōju [支光合う「移民時代] 複数 国籍「国民の受け止めは寛容」佐々木てる青森公立大教授].” Mainichi Shinbun [毎日新聞], 1 October. Accessed 3 November, 2019. https://mainichi.jp/ articles/20191001/k00/00m/040/152000c.

Yamada, J. [山田 順] 2018. “Osaka Naomi senshu wa Nihonjin de wa nai. Naze, buai no ì toki dake 'Nihonjin' ni shite shimau no ka? [大阪直美選手は日本 人ではない。なぜ、歩合のいいときだけ「日本人」にしてしまうのか?].” Yahoo! Japan News, 21 September. Accessed 21 August, 2019. https://news.yahoo.co.jp/ byline/yamadajun/20180921-00097718/.

Yamashiro, J. H. 2017. "From Hapa to Hāfu: Mixed Japanese American Identities in Japan.” In Redefining Japaneseness: Japanese Americans in the Ancestral Homeland, edited by H. Ling, 64-97. Canada, Ontario: Rutgers University Press. https://doi.org/10.36019/9780813576398.

THe

(1)

